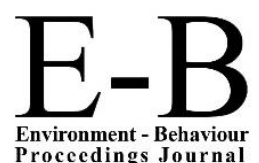

Environment - Behaviour

\section{CSSR 2017}

https://www.amerabra.org; https://fspu.uitm.edu.my/cebs; https://www.emasemasresources.com

$4^{\text {th }}$ International Conference on Science \& Social Research

The Pines, Malacca, Malaysia, 06 -07 December 2017

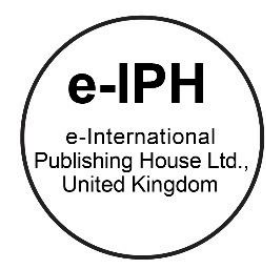

\title{
Migrant Workers with Social Security in Malaysia: Are they being discriminated against?
}

\author{
Namirah Mohd Akahsah 1, Muhammad Faliq Abd Razak ${ }^{2}$, \\ Mohd Safri Mohammed Na'aim ${ }^{1}$, Ainul Mardhiyyah Tajudin ${ }^{1}$
}

\author{
${ }^{1}$ Centre of Foundation Studies, Universiti Teknologi MARA, Dengkil, Selangor, Malaysia. \\ ${ }^{2}$ Institute of Malaysian \& International Studies (IKMAS), Universiti Kebangsaan Malaysia, Bangi ,Selangor , Malaysia
}

namirah9532@uitm.edu.my, faliqrazak@ukm.edu.my,safri7246@uitm.edu.my, ainul9561@uitm.edu.my

Tel: +60132755741

\begin{abstract}
Migration and cross-border mobility of workers are expected to further intensify in the coming years as the Association of South East Asian Nations (ASEAN) works towards a full regional integration. Malaysia is one of the countries that receive migrant workers supplied by sending countries in ASEAN. The initial finding shows that migrant workers in Malaysia face discriminatory treatment, with insufficient legal coverage under the existing laws. Using the qualitative research methodology, this article analyses the coverage and protection given under existing laws to migrant workers, which would ensure basic social and labour protection and with reference to International Labour Standard.
\end{abstract}

Keywords: Migrant workers; Discriminatory Treatment; Social and Labour protection; International Labour Standard

eISSN: 2398-4287 @ 2020. The Authors. Published for AMER ABRA cE-Bs by e-International Publishing House, Ltd., UK. This is an open access article under the CC BYNC-ND license (http://creativecommons.org/licenses/by-nc-nd/4.0/). Peer-review under responsibility of AMER (Association of Malaysian Environment-Behaviour Researchers), ABRA (Association of Behavioural Researchers on Asians) and cE-Bs (Centre for Environment-Behaviour Studies), Faculty of Architecture, Planning \& Surveying, Universiti Teknologi MARA, Malaysia.

DOI: https://doi.org/10.21834/ebpj.v5iSI1.2298

\subsection{Introduction}

Generally, migrant comes from the word 'migrating', which is the process of moving from one place, country, or locality to another (Oxford Dictionary). Meanwhile, the International Labour Organization (ILO) defines a migrant worker as a person who migrates from one country to another with a view of being employed. This definition also includes any person who is regularly admitted as a migrant for employment. There are different definitions from different set of instruments. For example, Article 2(1) of the International Convention on the Protection of the Rights of All Migrant Workers and Members of Their Families (adopted by the General Assembly resolution 45/158 of 18 December 1990 and entered into force in 2003) defines a migrant worker as a person who is to be engaged, is engaged, or has been engaged in a remunerated activity in a State that he, or she is not a national. It is well known that migrant workers are one of the key actors that have greatly contributed to the regional social and economic development in Southeast Asian countries, particularly in Malaysia. Processing migrant workers' policy formation and implementation is a challenging obstacle for any nation since it involves consistent effort to cater to the various needs of a nation. Malaysia, as a foreign worker-employing nation, has taken various approaches to avoid seeing employed foreign workers in allowed-industries as a national security issue. This explains the country's strict policies to address the influx of foreign workers. These policies are manifested in its law formations and amendments pertaining foreign labour employment, especially with regards to Article 22 of the Universal Declaration of Human Rights (UDHR) 1948, in conjunction with the right to social security for legally employed foreign workers. This paper is structured as follows: a brief introduction on migrant workers and social security; the issue of discrimination among migrant workers; and international and domestic legal instruments with law cases. Concluding remarks are made in the final section of this paper. 


\subsection{Literature Review}

As of today, the majority of these workers are economically weak, politically powerless, and socially marginalised (Zheng, 2016). They often come to the host countries where they perform jobs that the natives no longer want to do, the so-called 'three-D' jobs (dirty, degrading, and dangerous). These migrant workers are among the most vulnerable people in society. They are the least protected group, who may have been victimised in the form of abuse, as well as exploitative and discriminatory treatments (Abella, 2002). Therefore, migrant workers need to have their rights spatially and temporally protected, in the long transition process and at different locations before their final re-settlement (Zhu \& Lin, 2013).

\subsection{Methodology}

A qualitative approach was utilised for this research article to discuss the real position of migrant workers, who face discrimination by the Government of Malaysia and to offer recommendations to address this problem.

\subsection{Results}

Migrant workers are discriminated on their right to social security due to inadequacy and insufficiency of legal protection with the stand of the government of Malaysia. It is not feasible to include migrant workers under social security schemes. Malaysia is a renowned nation with high standards of domestic on its compliance with legislation to the international obligation to the ILO Fundamental Convention on labour standards. Though, the application and practice of domestic laws in Malaysia as discussed aforementioned in the section of the domestic framework should not discriminate migrant workers by excluding them from legal coverage and legal protection where they are in needs as employees. Good laws enacted are measured on the outcomes after the laws being enforced rather than making law in place only. Another way to deal with discrimination practices against migrant workers is by looking at the great contributions made by them as manpower in the host country, particularly which resulted to the development of infrastructure in Malaysia as such. In order to solve the issue, migrant workers should have the rights to the nine branches of social security, as previously discussed. Malaysian government should consider ratifying several of the international conventions related to Social Security, such as the (C118) Equality of Treatment by the International Labour Organization (ILO). By ratifying this convention, new legislations could be enacted at the domestic level to ensure the elimination of any form of discrimination against migrant workers as well as to protect their right to social security. The government should also strive to meet the minimum standards for two main conventions adopted by the ILO as international labour standards, namely, the Social Security (Minimum Standards) Convention, 1952 (No. 102) and the Equality of Treatment (Social Security) Convention, 1962 (No. 118), which are related to the social security of migrant workers. Last, but not least, the act of discrimination against immigrant workers by employers and governance systems in the government should be eliminated to protect the rights of these workers as a vulnerable group. Such endeavour will reflect positively on the host country for upholding human rights.

\subsection{Discussion}

\subsection{Migrant Workers with legal protection for their right to social security under International Legal Instruments}

Article 1, paragraph 1 of the International Convention on the Elimination of All Forms of Racial Discrimination (General Assembly resolution $2106 \mathrm{~A}(\mathrm{XX})$ annex) defines the term 'discrimination' as "any distinction, exclusion, restriction, or preference based on race, colour, descent, or national or ethnic origin, which has the purpose or effect of nullifying or impairing the recognition, enjoyment, or exercise, on an equal footing, of human rights and fundamental freedoms in the political, economic, social, cultural, or any other field of public life". Discrimination, in other words, is the "unfair behavioural biases" by a group of people towards another group of people. It compares the potential, ability, performance, or proven success among the differing groups (Diezt, 2010). Migrant workers all over the world are facing discrimination almost in every aspect of their life, including education, housing, work, health, and social security (UNHR). It usually occurs between local workers and migrant workers, which basically revolves around the treatments of the locals towards them. They are being discriminated against in their everyday life. For example, local customers prefer local workers over migrant workers. As the economy rises, social problems among migrant workers had also increased. In this case, discrimination occurs when protection of the branches of social security is neglected by the respective authorities.

Social security is defined as public policy measures aimed to protect members of the society against social and economic distress (ILO, 2010). It is a question of "meeting individual welfare needs and the rights of people to have these needs met whatever their citizenship or residence status is" (Bragg \& Feldmen, 2011). The history of social security started sometime between 1883 and 1884 when Otto von Bismarck established a social security system in Germany that since then, has been served as a type of model of social insurance (Scheinin, 2001). The idea was to drive the development in German machinery industries with the introduction of social security protections for workers in the form of disease insurance (1883), industrial accidents (1884), and pension insurance (1889). For example, workers and employers would make contributions to finance sickness insurance and workers' compensation. A few years later, the system was added to an old-age insurance program, and was partly financed through taxes. The main objectives of social security would be to offer social equality, social justice, as well as to secure social and political stability. The ILO Social Security (Minimum Standards) Convention, 1952 (No. 102) has classified the minimum standards for nine branches of social security, namely, 
medical (health) care benefit, sickness benefit, unemployment benefit, old-age benefit, employment injury benefit, family benefit, maternity benefit, invalidity benefit and survivors' benefit. Thus, social security is a fundamental human right (Art 22, UDHR, 1948; Art 9, ICESCR, 1976) to protect migrant workers as well as their families. It also works as a tool to prevent income insecurity, reduce poverty, as well as inequality, social exclusion, and social insecurity (ILO, 2012). However, a large majority of immigrants do not enjoy the full entitlement and benefit of this universal right (Zheng, 2016). According to ILO's version of the World Social Protection Report (2014/2015), only 27 per cent of the world's population has access to a comprehensive social security system, whereas 73 per cent is partially covered, or not covered at all by any social security programme.

The following Tables 1 to 4 shows Malaysia's ranking and rating against the international standards for migrant workers, as indexed by ILO and the International Trade Union Confederation (ITUC).

Table 1: Malaysia's ranking on the Violations of Worker's Rights

\begin{tabular}{|c|c|c|c|}
\hline \multicolumn{2}{|c|}{2016} & \multicolumn{2}{|c|}{2017} \\
\hline Malaysia's Ranking & 4 & Malaysia's Ranking & 4 \\
\hline
\end{tabular}

Table 2: Assessment Ratings used by ITUC:

\begin{tabular}{|c|l|}
\hline Ratings & \multicolumn{1}{|c|}{ ITUC Assessment towards Countries } \\
\hline $5+$ & No guarantee of rights due to the breakdown of the rule of law \\
\hline 5 & No guarantee of rights \\
\hline 4 & Systematic violations of rights \\
\hline 3 & Regular violations of rights \\
\hline 2 & Repeated violations of rights \\
\hline 1 & Irregular violations of rights \\
\hline
\end{tabular}

(Source: The 2016 and 2017 ITUC Global Rights Index (International Trade Union Confederation, 2016; 2017)).

Table 3: Ratification List for Malaysia on Branches of Social Security with related International Labour Instruments

\begin{tabular}{|l|c|c|c|c|}
\hline \multicolumn{1}{|l|}{ Malaysia } \\
\hline Medical care & $\mathrm{C} 102$ & $\mathrm{X}$ & $\mathrm{C} 130$ & $\mathrm{X}$ \\
\hline Sickness benefit & $\mathrm{C} 102$ & $\mathrm{X}$ & $\mathrm{C} 130$ & $\mathrm{X}$ \\
\hline Unemployment benefit & $\mathrm{C} 102$ & $\mathrm{X}$ & $\mathrm{C} 168$ & $\mathrm{X}$ \\
\hline Old-age benefit & $\mathrm{C} 102$ & $\mathrm{X}$ & $\mathrm{C} 128$ & $\mathrm{X}$ \\
\hline Employment injury benefit & $\mathrm{C} 102$ & $\mathrm{X}$ & $\mathrm{C} 121$ & $\mathrm{X}$ \\
\hline Family benefit & $\mathrm{C} 102$ & $\mathrm{X}$ & & $\mathrm{X}$ \\
\hline Maternity benefit & $\mathrm{C} 102$ & $\mathrm{X}$ & $\mathrm{C} 183$ & $\mathrm{X}$ \\
\hline Invalidity benefit & $\mathrm{C} 102$ & $\mathrm{X}$ & $\mathrm{C} 128$ & $\mathrm{X}$ \\
\hline Survivors' benefit & $\mathrm{C} 102$ & $\mathrm{X}$ & $\mathrm{C} 128$ & $\mathrm{X}$ \\
\hline
\end{tabular}

(Source: International Labour Standards on Social Security, International Labour Organization (ILO) 2017)

Table 4: Ratification List for Malaysia on the Main Convention Governing Social Security for Migrant Workers

\begin{tabular}{|c|c|c|c|}
\hline \multicolumn{4}{|c|}{ Malaysia } \\
\hline \multicolumn{4}{|c|}{ Social Security Convention } \\
\hline $\begin{array}{c}\text { Equality of Treatment } \\
\text { (Social Security) }\end{array}$ & $\begin{array}{c}\text { Maintenance of Social } \\
\text { Security Rights }\end{array}$ & $\begin{array}{c}\text { Equality of Treatment } \\
\text { (Accident Compensation) }\end{array}$ & $\begin{array}{c}\text { Maintenance of Migrants' } \\
\text { Pension Rights }\end{array}$ \\
\hline C118 & C157 & C019 & C048 \\
\hline$X$ & $\mathrm{X}$ & $\mathrm{X}$ & $\mathrm{X}$ \\
\hline
\end{tabular}

(Source: NORMLEX (Information System on International Labour Standards) Social Security for Migrant Workers, International Labour Organization (ILO) 2017

\subsection{Domestic framework governing right to social security for migrant workers}

Article 8 of the Federal Constitution (hereinafter 'FC') states that all persons are equal and should be entitled to equal protection under the law. The word used in this Article is 'persons', which covers all the people in Malaysia with no specific reference to only Malaysian citizens. Therefore, this provision indicates that everyone should be treated equally, subject to the conditions prescribed by the clauses in Article 8 of the FC. Hence, there should be no discrimination based on nationality. Based on the spirit of this Article, protection of social security should not only be accorded to Malaysian citizens, but also to migrant workers to ensure that their welfare and interests are safeguarded and well taken care of. This is because they have contributed to the development and growth of this country, in various economic sectors ranging from agriculture to manufacturing. To ensure that this protection is not abused and manipulated towards illegal employment of migrants, this provision is limited to legal migrant workers. The following sections will discuss the domestic laws that deal with the protection of social security for migrant workers in Malaysia.

\subsubsection{Employees' Social Security Act 1969}

The Social Security Organisation (SOCSO) was formed under the Employees' Social Security Act 1969 (hereinafter 'ESSA 1969'). It became a government department under the Ministry of Labour and Manpower on 1 January 1971 (SOCSO, 2017). The main 
responsibility of SOCSO is to administer two social security schemes, namely, the Employment Injury Scheme (hereinafter 'EIS') and the Invalidity Scheme (SOCSO). EIS provides coverage and protection for employees who suffer from employment injury. The words 'employment injury' is further explained in section 2 of the same Act to mean "a personal injury to an employee caused by accident, or an occupational disease arising in the course of his employment in an industry to which this Act applies". Examples of the protections covered under this scheme are industrial accidents while carrying out their duties; accidents while travelling; accidents that occur during an emergency; and occupational diseases. For the latter, the scheme provides 24-hour coverage to an employee who suffers from invalidity by reason of specific morbid condition of permanent nature. This could be either incurable or is not likely to be cured and no longer capable of earning by work corresponding to his strength and physical ability, or death due to any cause and not related to his employment.

In light of section 5 of the ESSA 1969, all employees employed by major industries, as defined by section 2 of the same act, shall be insured in accordance with the Act. The word 'industry' is defined as "any business, trade, undertaking, manufacture, or calling of employers", and it includes any calling, service, employment, handicraft, or industrial occupation, or avocation of employees. To who does the responsibility lies to ensure the employees are insured? A reference to sections 4 and 5 indicates that such responsibility will be borne by employers who have a minimum number of 5 employees in the defined industries. Failure to comply would mean actions can be taken by SOCSO under section 94 (g) of the ESSA 1969, where if found guilty, an employer can be imprisoned for a term of not exceeding two years, or fined, not exceeding RM10,000, or both. The important question is whether or not the ESSA 1969 applies to migrant workers? Tracing back to the early years of its operation, ESSA 1969 did apply to migrant workers. However, with the huge influx of foreign workers, problems began to emerge (Ragayah, Hwok, \& Saaidah, 2002). As a result, in 1993, all foreign workers were excluded from coverage under the ESSA 1969, with effect from 1 April 1993 (SOCSO, 2017). Alternatively, protection for injury suffered by migrant workers in the course of their employment is now covered by the Workmen's Compensation Act 1952. Pursuant to this section, all employers are required to ensure that their migrant workers are insured under the Foreign Worker Compensation Scheme with any insurers appointed by the Ministry of Human Resources (Department of Labour of Peninsular Malaysia, 2013). Through this insurance, the insurer will pay the compensation for any injuries sustained by the migrant workers in the course of their employment.

\subsubsection{Workmen's Compensation Act 1952}

The introduction for the Workmen's Compensation Act 1952 (hereinafter 'WCA 1952') shows that the Act aims to provide for the Payment of Compensation to workmen for any injury suffered in the course of their employment. The Act recognises the protection offered by social security for a migrant who works and unfortunately, suffers an injury at his workplace in Malaysia. Several provisions are contained in this Act to provide protection to migrant workers. First, pursuant to section 13 of the WCA 1952, every employer is required to give a written notice to the Commissioner, as defined by section 2 of the same Act, of any occurrence of any incident on his premise that causes death or immediate disablement, either total, or partial of any person injured. This provision ensures that employers take the necessary and reasonable actions to assist their injured migrant workers. In addition, it is compulsory for employers, under section 26(2) of the WCA 1952, to insure their migrant workers. As such, pursuant to this section, all employers are required to insure their migrant workers under the Foreign Workers Compensation Scheme with any insurers appointed by the Ministry of Human Resources (Department of Labour of Peninsular Malaysia, 2013). Theoretically, the insurers will pay the compensation for the injury sustained by the migrant workers in the course of their employment. This obligation is mandatory in which failure to comply is an offence under section 26(6) of the WCA 1952. If found guilty, the employer can be fined, not exceeding RM20, 000, or face imprisonment for a term of not exceeding two years, or both. In fact, this protection is a requirement for visa application.

In a recent 2015 High Court case, Alamgir illustrated one of the weaknesses in the existing legal framework, namely, the Workmen's Compensation Act 1952. In this case, a Bangladeshi foreign worker was employed by the Defendant's company, Cass Printing and Packaging Sdn Bhd, as a machine operator. While working, his hand was caught between the rollers of the machine, which resulted in an amputation of his hand. In this case, the employer failed to provide a safe working condition because safety grill was not attached to the machine despite several requests by the Plaintiff. The employer had also failed to give proper training to the Plaintiff. In addition, due to a permit issue, Cass Printing did not insure the Plaintiff. In this case, the court decided on behalf of the Plaintiff. The judge ruled that the Plaintiff was entitled to RM 80,000 for permanent disability, pain, and suffering. The Plaintiff was also awarded for loss of earnings and loss of future earnings amounting to RM230, 039.36 and for special damages at RM530. It was mentioned by the Judge in this case due to the reason being that the compensation is too low and unable to meet the present economic demand. This Act has never been revisited and amended. Thus, there is a need to amend the Workmen's Compensation Act 1952 because it is out-dated.

\subsubsection{Employment Act 1955, Sabah Labour Ordinance 1967, \& Sarawak Labour Ordinance 1952}

In general, the Employment Act 1955 applies only in Peninsular Malaysia. Meanwhile, Sabah and Sarawak are regulated by their respective laws, namely, the Sabah Labour Ordinance 1967 and the Sarawak Labour Ordinance 1952. They provide several protections that fall under social security extending to migrant workers. Despite the existence of a legal framework in Malaysia, as previously discussed, one case illustrated that the rights of a migrant worker were still being disregarded by the employer. In the case of Chin Well, the fifty-two (52) year old employee had migrated to Malaysia when he saw a job advertisement offering a salary of RM 600. The High Court of Pulau Pinang condemned the act of discrimination in this case by claiming that "This whole episode is a conspiracy by the Defendants, Amarjeet and Mithun, to cheat innocent workers who had mortgaged their lands, pledged, or sold their pieces of jewellery, so that they could earn a fair and reasonable sum from their employment." Instead, they were cheated, degraded, and denied basic food and amenities. 
The Chin Well case shows that despite having a legal framework, the biggest problem in Malaysia is that some employers would ignore and break the laws concerning foreign workers, even though they are aware of the legal obligations on the contract of employment. Hence, there is a lack in terms of law enforcement, where the employers would blatantly violate the employment contract and the law because they feel that there are no consequences in doing so. All workers should be treated with fairness, dignity, and equality without distinction, whether they are locals or migrants. Migrant workers are entitled to the same employment rights and benefits enjoyed by the local workers (P. Iruthayaraj D. \& Pappusamy, 2014).

\subsection{Conclusion}

Migrant workers are being discriminated against their right to social security due to inadequate and insufficient legal protection. The Malaysian government holds the stand that it is not feasible to include migrant workers under social security schemes. Malaysia is a renowned nation with high domestic standards in its compliance with legislations in the international obligation to the ILO Fundamental Convention on labour standards. Therefore, the application and practice of domestic laws in Malaysia should not discriminate migrant workers by excluding them from legal coverage and legal protection in places where they are in need as employees. The enacted laws are measured by the outcomes after the laws have been enforced. Another way to deal with discrimination practices against migrant workers is by looking at their great contributions as manpower in the host country, particularly when their contributions have resulted in the development of infrastructure in Malaysia. In order to solve the issue, migrant workers should have the rights to the nine branches of social security, as previously discussed. Malaysian government should consider ratifying several of the international conventions related to Social Security, such as the (C118) Equality of Treatment by the International Labour Organization (ILO). By ratifying this convention, new legislations could be enacted at the domestic level to ensure the elimination of any form of discrimination against migrant workers as well as to protect their right to social security. The government should also strive to meet the minimum standards for two main conventions adopted by the ILO as international labour standards, namely, the Social Security (Minimum Standards) Convention, 1952 (No. 102) and the Equality of Treatment (Social Security) Convention, 1962 (No. 118), which are related to the social security of migrant workers.

\section{Acknowledgments}

This research is funded by a grant from Universiti Teknologi Mara, UiTM (Lestari 121/2017).

\section{References}

Abella, M. I. (2004). Migrant workers' rights are not negotiable. Labour Education 2002/4 No. 129. Migrant Workers.

Alamgir v. Cass Printing \& Packaging Sdn. Bhd [2015] 7 MLJ 270.

Association, I. S. (2006). The role of social security in protecting migrant workers. ISSA Regional Conference for Asia and the Pacific, Retrieved from https://www.issa.int/en

Balogun, A. T. (2012). Occupational underemployment: A phenomenological study of professional legal immigrants in the United States. University of Phoenix: ProQuest LLC.

Bragg, R., \& R. Feldman (2011) An increasingly uncomfortable environment': Access to health care for documented and undocumented migrants in the UK, in R. Sabates Wheeler \& R. Feldman (eds). Social protection and migration: Claiming rights beyond borders, pp. 143-163. London: Palgrave Macmillan.

Dietz, J. (2010). Introduction to the special issue of employment discrimination against immigrants. Journal of Managerial Psychology. Emerald Insight, 25(2), 104-112.

Employees Provident Fund. (January 24, 2017). Retrieved from http://www.kwsp.gov.my/portal/en/about-epf/overview-of-the-epf

Hassan, K. H., \& George, C.M. (2009). External Migration of labour force and access to justice: Malaysian Law in the context of ILO standards. Retrieved from http://www.ialsnet.org/wordpress/wpcontent/uploads/2015/08/HassanGeorgeMalaysia.pdf

International Covenant on Economic, Social and Cultural Rights (entry into force 3 January 1976).

ILO Convention C102: Social Security (Minimum Standards) Convention, 1952 (No. 102).

ILO (2012b). 'Social Protection Floors for Social Justice and a Fair Globalization'. Geneva: International Labour Organisation.

P Iruthayaraj, \& D. Pappusamy. (2014). Migrant workers contribution towards the Malaysian economic transformation. Paper presented at Asian Conference on Globalization and Labor Administration: Cross-Border Labour Mobility, Social Security and Regional Integration.

Ragayah, M.Z., Hwok, A.L, \& Saaidah, A.R. (2002). Social protection in Malaysia. Social protection in Southeast and East Asia, 133.

Regmi, K., Naidoo, J., \& Regmi, S. (2009). Understanding the effect of discrimination in the workplace: A case study amongst Nepalese immigrants in the UK. Equal Opportunities International, 28(5), $398-414$.

Saiman, M. S., \& Jemon, S. (2014). Social security: Case of foreign workers in Sabah, Malaysia. Malaysian Journal of Business and Economics, $1(1), 87-102$. 
Scheinin, M. (2001). The right to social security. In C.K. Asbjorn Eide (Ed). Netherlands: Martinus Nijhoff Publisher.

SOCSO. (September 25, 2017). Retrieved from https://www.perkeso.gov.my/en/about-us/profile.html

Yu, P. (2014). Immigrant Home Health Workers Experiences: A Qualitative Description Study. Boston College: ProQuest LLC

Zheng, Y. (2016). Strengthening protection for Intra- ASEAN Migrant Workers' rights to social security: A perspective from the post-2015 ASEAN vision. Faculty of Law, Lund University.

Zhu, Y., \&, Lin, L. (2013) 'From 'integration into cities' to 'an integrated society': Women migrants' needs and rights in Fujian province, China', in T. Truong, D. Gasper, J. Handmaker \& S. Bergh (eds) Migration, gender and social justice: Perspectives on human insecurity. Heidelberg: Springer. 